\title{
Design of crosswalks for children A synthesis of best practice
}

\author{
Lars Leden ${ }^{a}$, Charlotta Johansson ${ }^{a}$, Peter Rosander ${ }^{a}$, Victoria Gitelman ${ }^{b}$, Per Gårder $^{c}$ \\ ${ }^{a}$ Luleå University of Technology, 97187 Luleå,Sweden, Lars.Leden@ltu.se or info@larsleden.com \\ ${ }^{b}$ Technion - Israel Institute of Technology, Haifa, 3200003, Israel \\ 'University of Maine, Orono, ME 04469, USA
}

International Co-operation on

Theories and Concepts in Traffic Safety

This paper was presented at ICTCT workshop.

ABSTRACT: $A$ synthesis of best practice was done to come up with a "best design" of crosswalks used by children. The analysis is based on studies from three sites in Sweden and three in Israel, research results concerning "ideal" interactions, and a review of additional countermeasures as described in the literature.

Our presumption is that actual vehicle speeds should be below $20 \mathrm{~km} / \mathrm{h}$ where children (aged 7 to 12 years) are crossing a street, especially if they are walking unaccompanied by an adult. The results of field studies show that a "best design" to reach this should include a speed-reducing device located before the crosswalk. The optimal distance from such a device to the crosswalk is about $10 \mathrm{~m}$ if the speed limit is $30 \mathrm{~km} / \mathrm{h}$ or lower. For streets with $50 \mathrm{~km} / \mathrm{h}$ speed limits, a longer distance of 15 to $20 \mathrm{~m}$ is needed and, as a complimentary measure, the crosswalk itself should also be elevated. At approaches with two lanes or more, multiple-threat conflicts occur due to vehicles overtaking stopped ones in the adjacent lane. These conflicts are a threat especially to children, as they often are hidden behind the stopped vehicle if it has stopped too close to the crosswalk. To provide a stronger message for alerting drivers to stop and to stop early, and not to overtake a stopped car in an adjacent lane, advanced yield bars or stop lines are needed. For those, a distance to the crosswalk of about $10 \mathrm{~m}$ is recommended. To secure travel speeds below $20 \mathrm{~km} / \mathrm{h}$, additional measures like camera enforcement of speeds near the crosswalk might be needed.

Within a few years, ITS technology may govern speeds at marked crosswalks, and speed-reducing measures will be less needed at that time. However, for the foreseeable future, older vehicles lacking such technology will still be allowed on streets and even in newer vehicles, speed-control systems may be voluntary and possible to switch off. Therefore, we believe that investments into the measures discussed in this paper will have a role to play for decades to come.
KEYWORDS: Crosswalk, pedestrian, children, speed, speed-reducing devices, yield and stop lines

\section{STATE OF THE ART}

\subsection{Children and traffic - an introduction}

Traffic signs and road markings can be used to increase the awareness among drivers, for example when they approach crossing points used by children. Also, different types of enforcement can be effective in influencing behavior. Another approach is that of the concept of "shared space" (Fontaine \& Carlson, 2001, and Daniel, Chien, \& Liu, 2005). Currently, applications of the "shared space" concept, i.e. assuming walking speeds of motor vehicles, are reported from several countries, including the Netherlands where a predecessor to shared spacethe Woonerf concept-was launched in the 1970's. Different concepts of "shared space" could be used more extensively in walking-speed zones and at intersections where pedestrians dominate (Gustafsson, Jägerbrand \& Grumert, 2011). The primary explanation for the probably positive effect on traffic safety of shared space is the lower speed level and higher attention to pedestrians among motorists and improved mobility for pedestrians (Sørensen, 2010). When we spend longer time in near proximity with strangers, we become more polite and are more likely to yield.

Höskuldur (2015) concludes that if the goal is to eliminate serious injury accidents, $30 \mathrm{~km} / \mathrm{h}$ might not be a sufficiently low speed. The actual vehicle speed should be a maximum of $20 \mathrm{~km} / \mathrm{h}$ where there is a risk of collision between vehicles and unprotected road users. This is of utmost importance on streets where children aged 7 to 12 cross (Johansson \& Leden, 2010) since children have difficulties 
estimating direction, speed and distance (Piaget 1969, von Hofsten, 1980 and 1983 (both presented in Arnold \& Bennett, 1990), Leden, 1989, Connely et al, 1998, Foot et al, 1999, Mac Gregor et al, 1999). To summarize, actual vehicle speeds should be below $20 \mathrm{~km} / \mathrm{h}$ where children (aged 7 to 12 years) are crossing a street.

Morrongiello et al. (2015) used a virtual environment to examine how two groups of children, aged eight and 10 years, cross streets, and especially the effect of vehicle speed, distance and intervehicle gaps. They found that children use distance cues in deciding when to cross in a dysfunctional way which increases their injury risk. They also concluded that there are no clear age or sex differences in behavior among children, at least not for those below age 12 . Morrongiello \& Corbett, M. (2015) used a virtual environment to examine how two groups of children, 7-9 and 10-12 years old, respectively, and their parents interacted. The researchers concluded that parents significantly overestimate the intervehicle gap threshold of their children, erroneously assuming that their children would show safer pedestrian behaviors and select larger intervehicle gaps for crossing than they actually did; again, there were no effects of child age or sex. The results support our study design focusing on all children between the ages of 7 and 12 .

To improve clarity and orientation and consequently pedestrian safety, refuge islands are efficient (Harkey \& Zegeer, 2004; Turner et al, 2006). Another option is to limit the number of directions vehicles can approach from e.g. by relocating crosswalks to mid-block locations (Leden, Gårder \& Johansson, 2006). However, there are studies indicating that midblock crosswalks have a higher risk than crosswalks at intersections due to higher speeds (Ekman, 1997). Thus, a maximum speed of $20 \mathrm{~km} / \mathrm{h}$ at midblock locations is crucial.

Speed for traffic-calmed roads as a function of the local speed and the type and design of the measure are shown, e.g., in Johansson \& Leden (2007), and as a function of the distance between measures in, e.g., Barbosa et.al. (2000) and Karlgren (2001). Similarly, drivers' and pedestrians' behavior at pedestrian crossings has been extensively researched, see, e.g., Johansson (2004) and Várhelyi (1998). However, the influence of the distance between a speed hump and a pedestrian crossing was not a focus of any study until 2011, when it was concluded that the optimal distance from such a device to the crosswalk is about
$10 \mathrm{~m}$ if the speed limit is $30 \mathrm{~km} / \mathrm{h}$ or lower (Johansson, Rosander \& Leden, 2011). Swedish guidelines still do not discuss the distance between the speed hump and the crossing explicitly. Recent Swedish guidelines for geometric design of roads and streets states that "Regular humps 5-6 m ahead of crosswalks typically work better than raised crosswalks, so called speed tables." (VGU, 2015). We will explore if the 5-6 $\mathrm{m}$ is in accordance with the best practice starting with the results of Várhelyi (1998).

Várhelyi (1998) analyzed drivers' speed behavior at a mid-block crosswalk using a radar gun, hidden at the roadside. The radar gun sent the speed data to a laptop computer in which the observers also registered pedestrians' arrival at, and start from, the curb. Of the total registered situations, the pedestrian is given priority and passes in front of the vehicles in 42 cases. Situations in which the pedestrian passes first include three types of situations: 'no braking' situations, 'provoked braking' situations, and 'ideal' situations from the point of view of the pedestrian. In 'ideal' situations the driver starts braking between 30 and $70 \mathrm{~m}$ before the crosswalk and speeds are the lowest 20 to $10 \mathrm{~m}$ before the crosswalk, see Figure 1 . Várhelyi \& Leden (discussion at ICTCT, 2016) conclude that a placement of speed humps in the range of 20 to $10 \mathrm{~m}$ before a crosswalk support 'ideal interactions.'

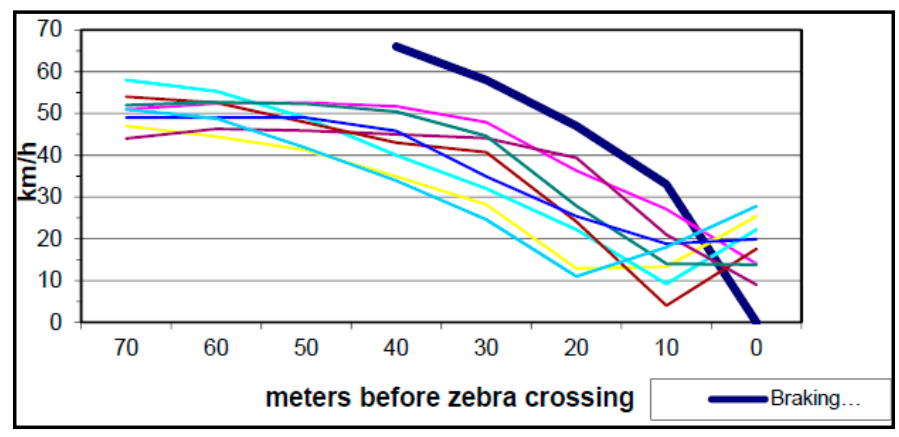

Figure 1. Speed profiles for "ideal" interactions when the driver gives way to the pedestrian well in advance (Várhelyi, 1998).

\subsection{Speed cushions design - a comparison between Sweden, Finland and Norway}

For all types of speed-reducing devices, the long-term effectiveness will vary not only with the design but also with factors such as the strength of the material, and how well the devices are constructed and maintained (Rosander, Lyckman \& Johansson, 2007). Especially the transition point between a prefabricated 
part of a speed cushion and the asphalt has to be designed to be smooth to avoid shocks that deteriorate the speed-reducing device. Figure 2 shows cracks on one of the two speed cushions at the test site at Tessins väg and Figure 3 shows how to avoid that through the "Norwegian solution" as described in an e-mail from Salermo, 2018.

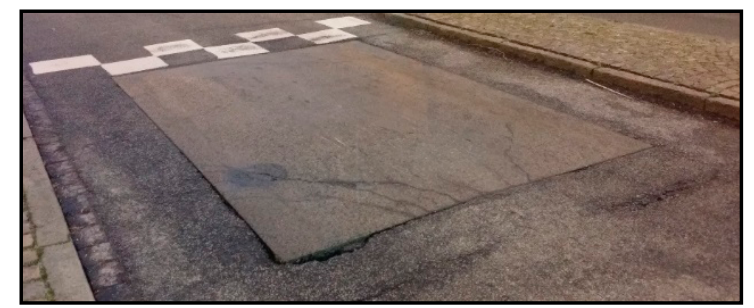

Figure 2. Cracks on one of the two speed cushions at Tessins väg (photo by Rolf Lysenius, February 2018).

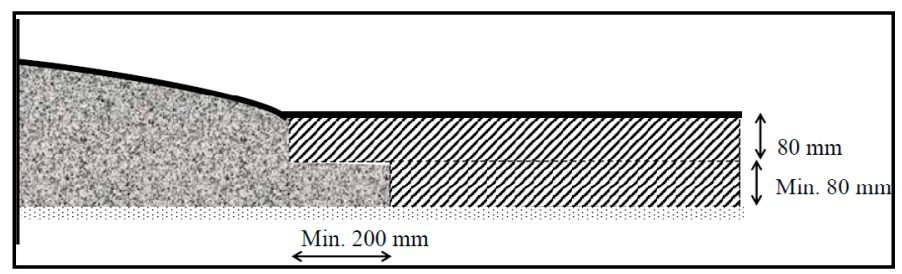

Figure 3. Transition between prefabricated speed cushion and asphalt surface.

The height of the speed cushion used at the test sites in Malmö was designed to be $8 \mathrm{~cm}$, see Figure 4 . The total length in the driving direction, excluding the flat part of the prefab part, is $3.6 \mathrm{~m}$. The up and down grades are 1:10.

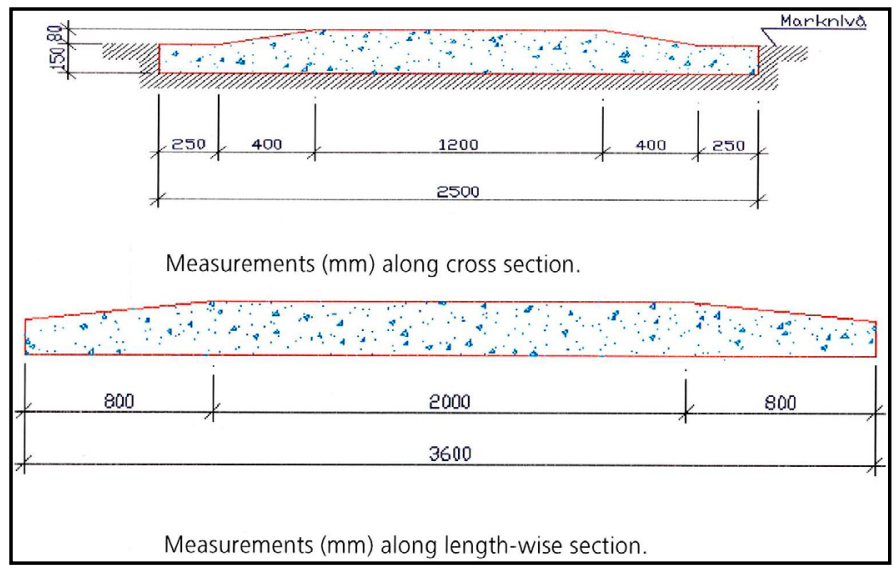

Figure 4. Design of speed cushion in Malmö (Towliat, 2001). Measurements in mm.

In Finland, the proposed design is slightly smoother than the one used at the Swedish test sites. The height is $7 \mathrm{~cm}$ and the length is $3.4 \mathrm{~m}$, giving a total length in the driving direction, excluding the flat part of the prefab construction, of $4.1 \mathrm{~m}$. The up and down grades are 1:10, as shown in Figures 5 and 6, just like at our test sites in Malmö.

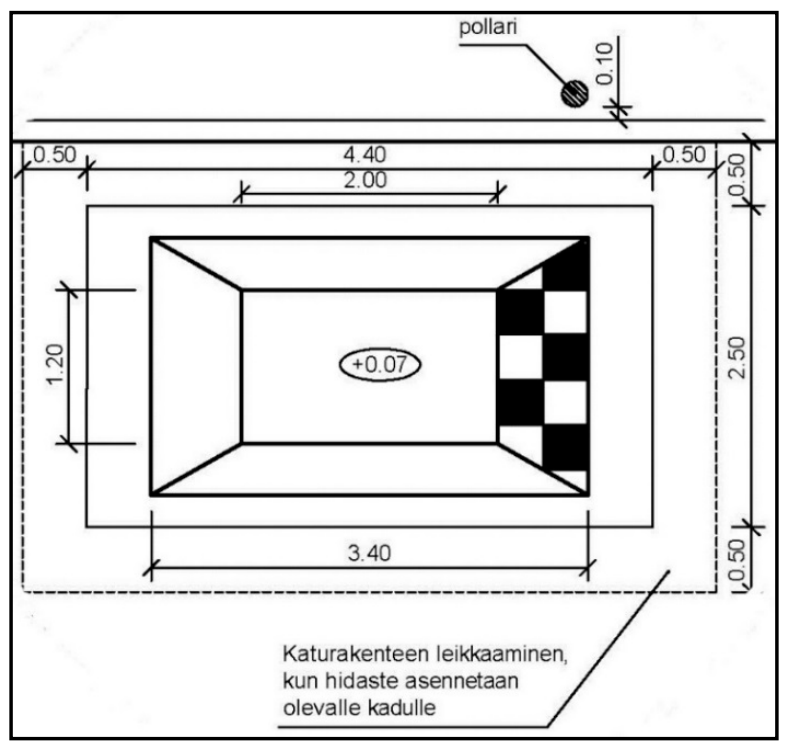

Figure 5. Finnish speed cushion design detail. Note: The outer area is also cut when installing the speed cushion (mail from Salermo, City of Helsinki, 2018).

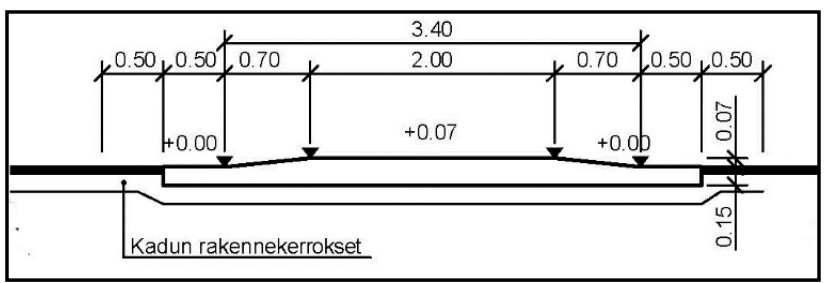

Figure 6. Profile (in driving direction) of Finnish recommendation. Note: Street structure layers in the outer cut area (mail from Salermo, City of Helsinki 2018).

Apart from using good design to get acceptable performance, it is important to inform drivers, especially bus drivers and other commercial drivers, about the aim of the intervention. Else, they may not drive in a safe and comfortable way.

\section{SCOPE AND METHOD}

The scope of this paper is to sum up the best practice for designing crosswalks for children focusing on physical measures like speed humps, speed cushions, speed tables (also called raised pedestrian crosswalks) and road markings. ITS technology is not included. For an overview of the methodology used for reviewing the research, see e.g. Light \& Pillemer (1984).

The basis for the analysis is studies from three sites in Sweden and three in Israel, Várhelyi's (1996, 
1998) analysis of speed profiles for "ideal interactions" (Figure 1), and a review of additional countermeasures as needed, to outline a best practice when designing crosswalks used by children.

To further describe pedestrian safety at crosswalks, video recordings were made of pedestrians waiting at the curb or crossing the street by a set of two cameras, one for the overview and the other one filming crossing pedestrians. The basis for the coding of the video recordings was work presented by Øvstedal and Ryeng (1999). A pilot study was done with data from Regementsgatan in Malmö, Sweden and Hultagatan in Borås, Sweden, including a small test on the reliability of observers' estimates of speeds and "time to accident" in traffic conflict situations to ensure that accurate results were found (Johansson et al., 1999). However, the construction of the countermeasures, the design of the study, the data collection, and especially, the coding of the data was very time consuming. A way to make the coding of parameters faster is to exclude some of the coded parameters that are less important in the studied traffic environment. The most important parameters seem to be the speed of motor vehicles, walking speed of pedestrians, cyclists' speed, if the pedestrian or cyclist stops at the curb or not, and if the pedestrian or cyclist looks around for traffic before crossing the road. Also, the data can be stratified with respect to the pedestrians' or cyclists' age. A comprehensive methodology for analyzing the data was presented by Johansson (2001). The parameters to be used are listed below, ranked starting with the most important one according to an expert questionnaire, based on the experts' evaluation of High Severity Situations and Conflicts gathered at four sites in Borås. Nine out of 26 contacted experts gave full responses. The expert questionnaire was sent to the recipients by e-mail. One advantage of sending it by e-mail is that the distribution is easy. The big disadvantage with digital video cuts is that the sizes of the files become large if more than a few seconds are to be included, so large that not all e-mail servers can receive them. A shorter questionnaire may have resulted in higher response rates. Here are the parameters ranked by importance:

1. speed of vehicles (measured by radar or laser),

2. speed of pedestrians or bicyclists (estimated from video),

3. at what distances evasive actions are taken (estimated from video),
4. whether the pedestrian or cyclist looks around before crossing the street (estimated from video), and

5. whether she/he stops at the curb before crossing the street.

Those parameters were chosen as key variables for analysis of both the Swedish and Israeli studies. In the Swedish studies, questionnaires and interviews with children were performed through cooperation with schools in the neighborhood. The basis of this method is presented by Leden (1989).

\section{TEST SITES}

As mentioned, studies from three sites in Sweden and three in Israel form the basis of our recommendations, together with review of additional countermeasures as needed. The aim is to outline a best practice of crosswalks in urban areas. The Israeli test sites were all major multi-lane arterials with dual-carriageway layouts. The Swedish test sites were on two-lane arterials. All sites were equipped with speed-reducing humps or cushions at varying distances from the pedestrian crosswalks.

On the Swedish test sites, teachers and schoolchildren from schools in the neighborhood were informed and in one case involved in the planning of the countermeasures (Johansson \& Rosander, 2006). Apart from this action traffic education was integrated in other subjects studied. There is no reason to believe that training or other actions performed at these schools have biased the research results since similar traffic education is part of the curriculum at all schools in Sweden (Gregerson, 2016).

\subsection{Test sites in Israel}

The Israeli test sites are multi-lane arterials with dual-carriageway layout and all have high traffic volumes and high pedestrian activity in the crossing areas. The selection criteria for the study sites were as follows:

- A marked crosswalk situated on a dual-carriageway road segment, with a raised median and two travel lanes in each direction.

- A speed limit of $50 \mathrm{~km} / \mathrm{h}$, where the 85 -percentile speed is above $50 \mathrm{~km} / \mathrm{h}$, at least in one of the directions approaching the crosswalk. 
- An intensity of pedestrian activity with at least 25 pedestrian crossings per hour.

- A straight and flat road segment (without sharp curves or substantial gradients), with a visibility distance for the driver of at least $50 \mathrm{~m}$ ahead in both directions approaching the crosswalk.

- A site without substantial visibility obstacles in the crosswalk area, such as dense vegetation.

The original study (Gitelman et al., 2017) included eight sites that were not selected from the vicinity of schools. However, at three sites A, B and C, included in that paper, there were high shares of child pedestrians below the age of 18 . Table 1 presents the site characteristics. The sites were selected in three different cities. Each site includes two pedestrian crosswalks, situated on different travel routes and divided by a median. The sites present a combination of various levels of vehicle and pedestrian traffic: medium vehicle traffic at Sites A, B and low - at Site C; low level of crossing pedestrians at Site $C$, medium - at Site A and high - at Site B. Among crossing pedestrians observed at the sites (in six hours), $31-45 \%$ were children.

Two countermeasure settings were applied in the Israeli study: (1) a bolder $15 \mathrm{~cm}$ high trapezoidal

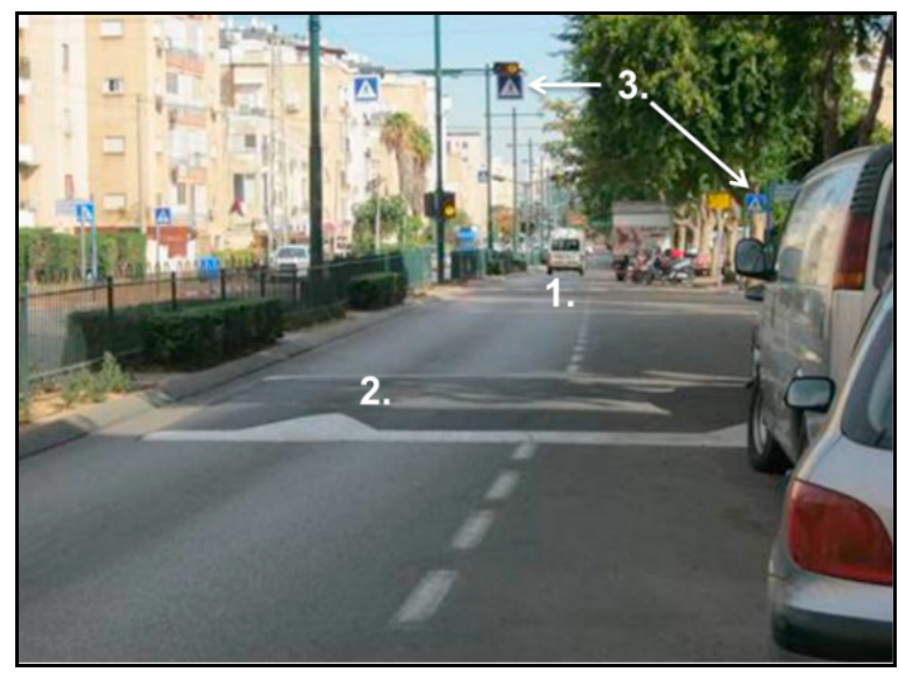

Notes: 1 - a trapezoidal speed hump in the crosswalk area; 2 - a circular speed hump before the crosswalk; 3 - traffic signs and overhead amber flashing lights.

Figure 7. Main components of a raised crossing arrangement, on the example of Site B in Israeli study.

speed hump at the crosswalk area, combined with 8-10 cm high circular humps (Watt's type) before the crosswalk - at Sites A and C, and (2) a smoother 10-12 cm high trapezoidal hump at the crosswalk area, combined with preceding circular humps that are 6-8 cm high - at Site B. At Sites A and C, a common length of the circular hump was 3-4 m,

Table 1. Sites in Israeli study, with estimates of their traffic and pedestrian volumes in various observation periods, and pedestrian age groups.

\begin{tabular}{|c|c|c|c|c|c|c|c|c|c|c|c|}
\hline \multirow[t]{2}{*}{$\begin{array}{l}\text { Study's } \\
\text { site }\end{array}$} & \multirow[t]{2}{*}{ City } & \multirow[t]{2}{*}{$\begin{array}{l}\text { Travel } \\
\text { direction }\end{array}$} & \multicolumn{3}{|c|}{$\begin{array}{l}\text { Average traffic volume, } \\
\text { vehicles per hour (sd) }\end{array}$} & \multicolumn{3}{|c|}{$\begin{array}{l}\text { Average number of } \\
\text { crossing pedestrians, per } \\
\text { hour (sd) }\end{array}$} & \multicolumn{3}{|c|}{ Pedestrian age groups (\%) ${ }^{a}$} \\
\hline & & & Before & After1 & After2 & Before & After1 & After2 & $\begin{array}{l}\text { Child } \\
\text { below } 18\end{array}$ & $\begin{array}{l}\text { Adults } \\
(19-64)\end{array}$ & $\begin{array}{l}\text { Elderly } \\
65+\end{array}$ \\
\hline \multirow[t]{2}{*}{ Site A } & $\begin{array}{l}\text { Hod } \\
\text { Hasharon }\end{array}$ & To west & $\begin{array}{l}447 \\
(161)\end{array}$ & $\begin{array}{l}551 \\
(158)\end{array}$ & $\begin{array}{l}582 \\
(243)\end{array}$ & $\begin{array}{l}72 \\
(23)\end{array}$ & $\begin{array}{l}71 \\
(34)\end{array}$ & $\begin{array}{l}75 \\
(42)\end{array}$ & 45 & 54 & 1 \\
\hline & & To east & $\begin{array}{l}588 \\
(184)\end{array}$ & $\begin{array}{l}668 \\
(166)\end{array}$ & $\begin{array}{l}575 \\
(154)\end{array}$ & $\begin{array}{l}70 \\
(34)\end{array}$ & $\begin{array}{l}69 \\
(29)\end{array}$ & $\begin{array}{l}71 \\
(40)\end{array}$ & & & \\
\hline \multirow[t]{2}{*}{ Site B } & Netanya & To north & $\begin{array}{l}646 \\
(71)\end{array}$ & $\begin{array}{l}695 \\
(74)\end{array}$ & $\begin{array}{l}620 \\
(61)\end{array}$ & $\begin{array}{l}151 \\
(36)\end{array}$ & $\begin{array}{l}132 \\
(30)\end{array}$ & $\begin{array}{l}134 \\
(53)\end{array}$ & 31 & 69 & 1 \\
\hline & & To south & $\begin{array}{l}519 \\
(76)\end{array}$ & $\begin{array}{l}566 \\
(73)\end{array}$ & $\begin{array}{l}606 \\
(58)\end{array}$ & $\begin{array}{l}131 \\
(35)\end{array}$ & $\begin{array}{l}129 \\
(24)\end{array}$ & $\begin{array}{l}147 \\
(34)\end{array}$ & & & \\
\hline \multirow[t]{2}{*}{ Site C } & Karmiel & To north & $\begin{array}{l}341 \\
(81)\end{array}$ & $\begin{array}{l}271 \\
(55)\end{array}$ & $\begin{array}{l}236 \\
(51)\end{array}$ & $\begin{array}{l}27 \\
(14)\end{array}$ & $\begin{array}{l}33 \\
(14)\end{array}$ & $\begin{array}{l}24 \\
(11)\end{array}$ & 31 & 66 & 3 \\
\hline & & To south & $\begin{array}{l}306 \\
(62)\end{array}$ & $\begin{array}{l}322 \\
(90)\end{array}$ & $\begin{array}{l}260 \\
(64)\end{array}$ & $\begin{array}{l}29 \\
(14)\end{array}$ & $\begin{array}{l}31 \\
(13)\end{array}$ & $\begin{array}{l}24 \\
(9)\end{array}$ & & & \\
\hline
\end{tabular}

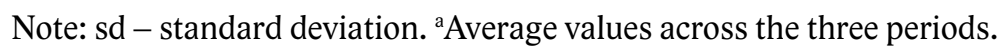


and a typical length of the trapezoidal hump (width of crosswalk) was $4 \mathrm{~m}$, with moderate up and down slopes, of 1:10. At Site B, the circular humps were longer $(5 \mathrm{~m})$, and the slope of the trapezoidal hump was more moderate (a slope of 1:20). Such variations are possible according to the Israeli guidelines (MoT, 2002). The circular speed hump is located $15-20 \mathrm{~m}$ before the crosswalk, in each travel direction and lane approaching the crosswalk. Figure 7 illustrates the main components of the raised crossing arrangement from Site B. Figure 8 provides typical layout of a raised crosswalk according to the Israeli guidelines. Figure 9 illustrates the views of Sites A and C after the installation of the raised crosswalks.

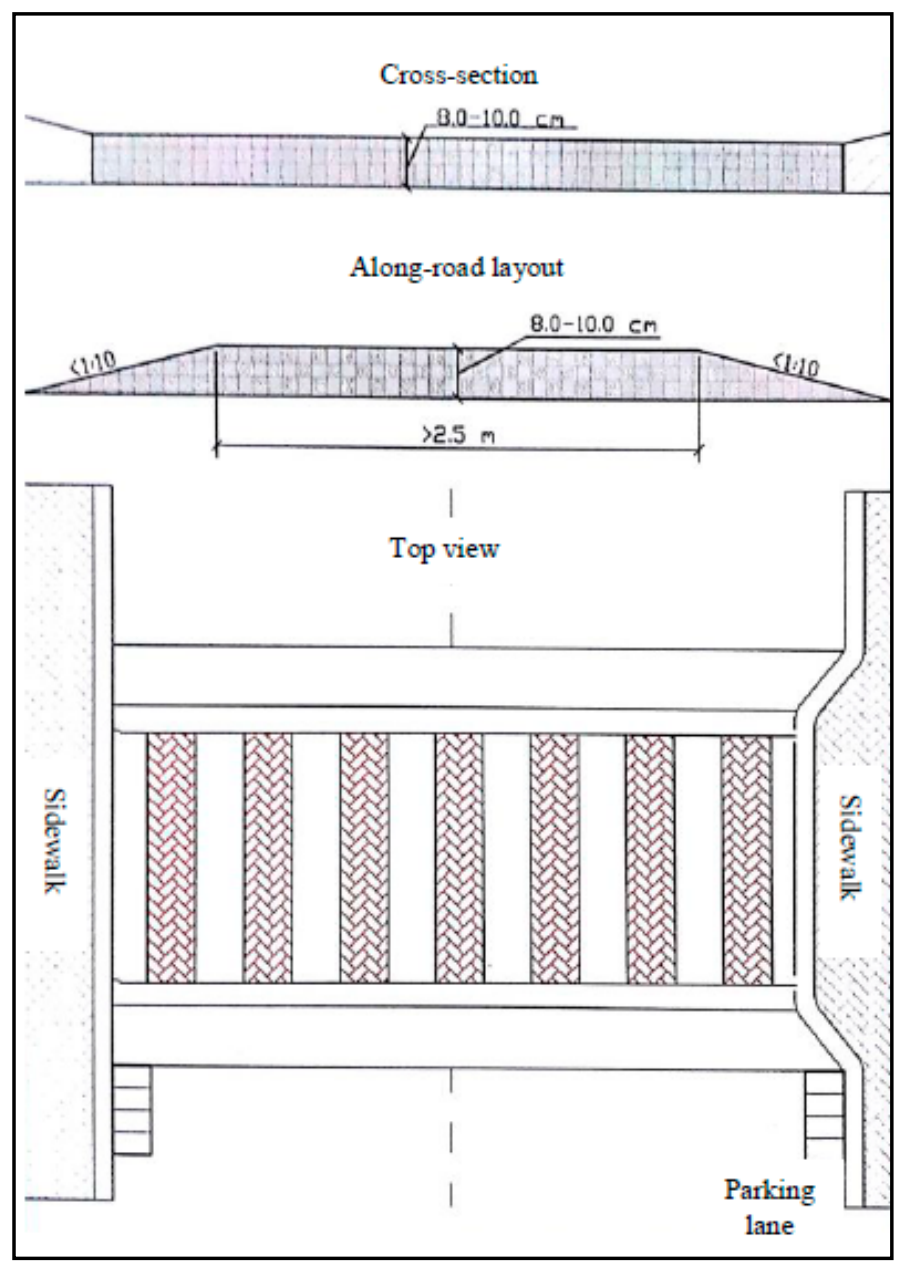

Figure 8. Typical layout of a raised crosswalk according to Israeli guidelines (MoT, 2002).

\subsection{Test sites in Malmö}

In the winter of 2000 and spring of 2001, before the reconstruction, Regementsgatan was a $15 \mathrm{~m}$ wide arterial in Malmö, with one marked lane in each direction. Though, in reality, it operated as two lanes in each direction when there were no parked cars. At each marked crosswalk, there was a refuge island.
Site A

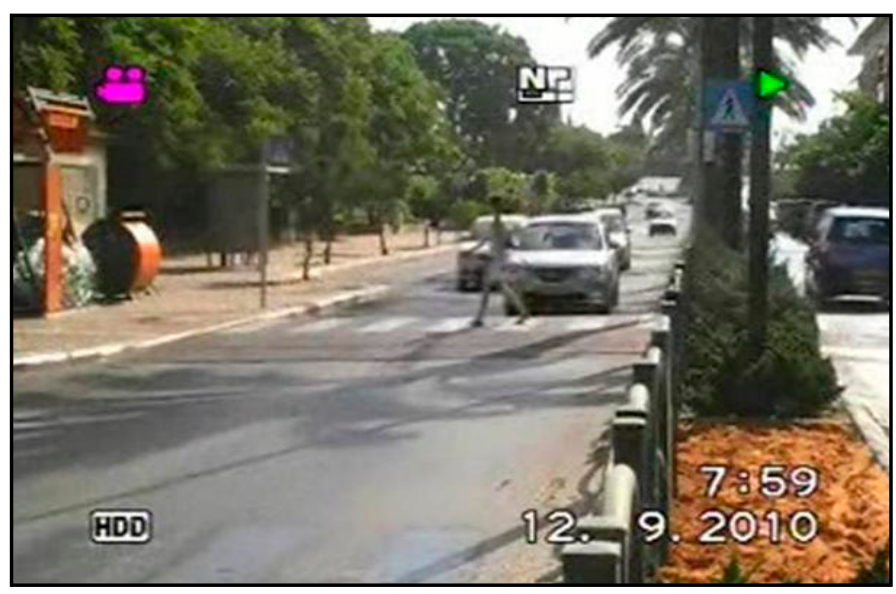

Site C

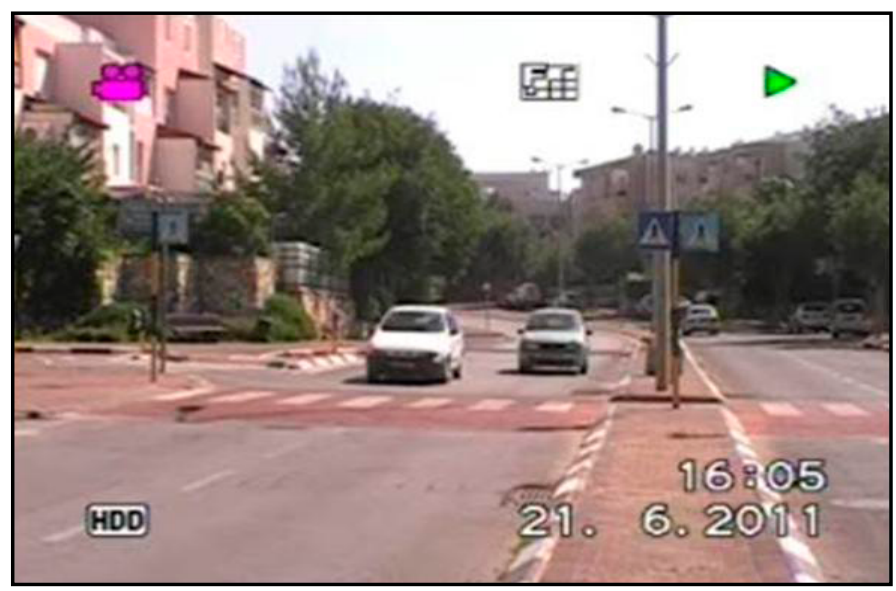

Figure 9. Sites $A$ and $C$, after the installation of the raised crosswalks, in Israeli study.

The traffic flow at Regementsgatan before the reconstruction was about 14,000 vehicles per day. The traffic volume decreased to just below 10,000 vehicles after the reconstruction. The street was narrowed to $8 \mathrm{~m}$ with refuges in the middle of the crosswalks, and speed cushions were installed before the crosswalks. The traffic signal was removed from the mid-block pedestrian and cyclist crossing at Dragonstigen. This site "Dragonstigen" was chosen as a test site as the two speed cushions were located at different distances, approximately $5 \mathrm{~m}$ and $10 \mathrm{~m}$ (actually, $8.8 \mathrm{~m}$ ) ahead of the marked pedestrian crosswalk, see Figure 10. The height of the speed cushion was designed to be $8 \mathrm{~cm}$ but was measured to vary from 7 to $10 \mathrm{~cm}$. The total length in the driving direction, excluding the flat part of the prefab part, is $3.6 \mathrm{~m}$. The up and down grades are moderate at about 1:10.

The second test site, "Tessins väg" in Malmö, is situated next to a school. Two school surveys administered by the teachers were launched there; one before, to get a foundation to plan countermeasures, and one after the reconstruction to evaluate the per- 


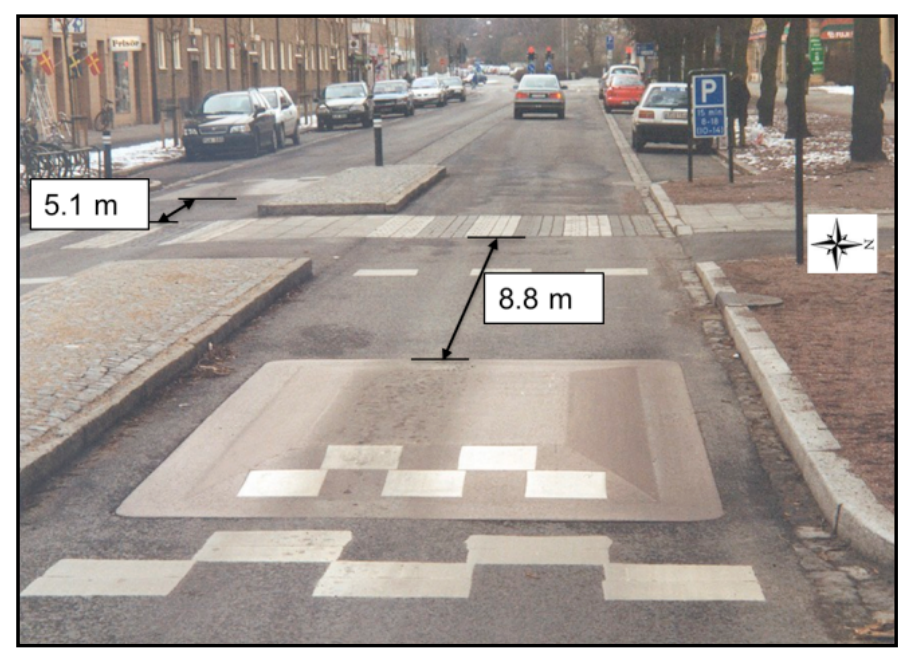

Figure 10. Test site "Dragonstigen" with a mid-block pedestrian and cyclist crossing.

ceived effects (Johansson. \& Rosander 2007). The distance between the pedestrian crossing and the speed cushion is $4.2 \mathrm{~m}$ for traffic travelling northeast, and $10.2 \mathrm{~m}$ for vehicles travelling south-west, see Figure 11. Crossings and speed cushions are indicated with painted markings, and the height of the speed cushions is about $10 \mathrm{~cm}$. The posted speed limit through the crossing is $30 \mathrm{~km} / \mathrm{h}$ at school hours, and a $50 \mathrm{~km} / \mathrm{h}$ when school is off. Tessins väg had a vehicle flow of 4,000 vehicles per day in 2005 .

\subsection{Test site in Borås}

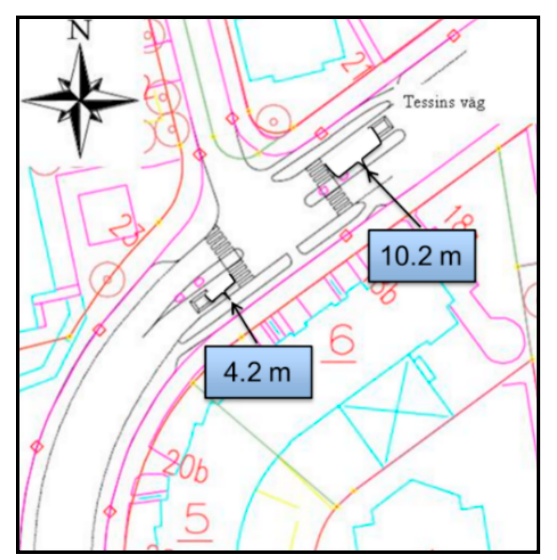

Figure 11. Plan of test site Tessins väg (the Tessins väg/ Henrik Wranérs gata intersection) after reconstruction. The shorter distance is $4.2 \mathrm{~m}$ to the left in the figure, and the longer distance is $10.2 \mathrm{~m}$.

The test site in Borås, Hultagatan, is at a mid-block pedestrian and cyclist crossing. It had a daily vehicle flow of 5,000 vehicles in 2001. The Hulta Centre with schools with students from first to sixth grade and businesses is located south of the studied site. The posted speed limit was $50 \mathrm{~km} / \mathrm{h}$ but the recommended speed was $30 \mathrm{~km} / \mathrm{h}$. The distance between the speed cushion and the pedestrian crossing is $3 \mathrm{~m}$ for traffic travelling east and $8 \mathrm{~m}$ for vehicles travelling west, see Figure 12. The height of the speed cushions is $70 \mathrm{~mm}$. School children cross the street frequently at this location as there is a nearby school and that was a reason for choosing this site.

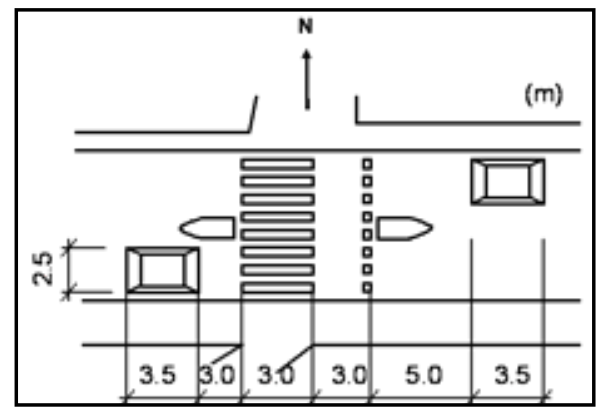

Figure 12. Test site "Hultagatan" in Borås is a mid-block pedestrian and cyclist crossing. The shorter distance between cushion and crosswalk is $3 \mathbf{m}$ to the left in the figure and the longer distance is $8 \mathrm{~m}$.

\subsection{Overview of countermeasures implemented}

Table 2 shows an overview of the countermeasures implemented at the test sites both in Israel and in Sweden.

\section{RESULTS}

\section{1 Israeli test sites}

Table 3 presents a summary of speed indicators at the study sites before and after the installation of the raised crossings. They characterize the travel speeds of vehicles approaching the crosswalk areas in both travel directions. In all cases, following the installation of a raised pedestrian crossings, vehicle travel speeds were reduced significantly.

The bolder design - at Sites A and C, led to a substantial reduction in speeds, achieving mean speeds below $30 \mathrm{~km} / \mathrm{h}$ and 85 -percentile speeds below $40 \mathrm{~km} / \mathrm{h}$. This was attained at sites with a wide range of initial mean speeds $(44-55 \mathrm{~km} / \mathrm{h})$ and 85 -percentile speeds $(56-65 \mathrm{~km} / \mathrm{h})$, thus, demonstrating a speed-reducing effect of $20-30 \mathrm{~km} / \mathrm{h}$ in both speed indicators. Moreover, the speed reductions attained due to the treatment were maintained over time, where substantially lowered travel speeds were observed both immediately after the installation of the raised crosswalks and two months later. 
Table 2. Type of countermeasures studied in three Swedish and three Israeli test sites.

\begin{tabular}{lccccccc}
\hline & $\begin{array}{c}\text { Narrowing } \\
\text { of street at } \\
\text { pedestrian } \\
\text { crossing }\end{array}$ & $\begin{array}{c}\text { Speed } \\
\text { humps }\end{array}$ & Cushions & $\begin{array}{c}\text { Distance } \\
\text { cushions / } \\
\text { humps to } \\
\text { crosswalk }\end{array}$ & $\begin{array}{c}\text { Elevated } \\
\text { area/ elevated } \\
\text { crossing with } \\
\text { paving stones }\end{array}$ & $\begin{array}{c}\text { Posted } \\
\text { speed } \\
\mathrm{km} / \mathrm{h} \\
\text { Before }\end{array}$ & $\begin{array}{c}\text { Recommended/ } \\
\text { Posted speed } \\
\mathrm{km} / \mathrm{h} \\
\text { After }\end{array}$ \\
\hline $\begin{array}{l}\text { Israeli test sites } \\
\text { Swedish test sites: }\end{array}$ & & Yes & & $15-20 \mathrm{~m}$ & Yes & 50 & 50 \\
Dragonstigen, Malmö & Yes & & Yes & $5.1 \mathrm{~m} / 8.8 \mathrm{~m}$ & & 50 & 50 \\
Tessins väg, Malmö & Yes & & Yes & $4.2 \mathrm{~m} / 10.2 \mathrm{~m}$ & 30 & 30 \\
Hultagatan, Borås & Yes & & Yes & $3.0 \mathrm{~m} / 8.0 \mathrm{~m}$ & 30 & $30 / 50$ \\
\hline
\end{tabular}

Table 3. Summary of speed indicators at Israeli sites, in various observation periods, and examination of their changes between the periods.

\begin{tabular}{lllllllllll}
\hline Site & Travel direction & \multicolumn{3}{c}{ Mean speed, $\mathrm{km} / \mathrm{h}$} & \multicolumn{3}{c}{ 85-percentile speed, $\mathrm{km} / \mathrm{h}$} & \multicolumn{3}{c}{ Changes between periods* $^{*}$} \\
\cline { 3 - 10 } & & Before & After1 & After2 & Before & After1 & After2 & $\begin{array}{l}\text { After1 } \\
\text { vs. Before }\end{array}$ & $\begin{array}{l}\text { After2 } \\
\text { vs. Before }\end{array}$ & $\begin{array}{l}\text { After2 } \\
\text { vs. After1 }\end{array}$ \\
\hline \multirow{2}{*}{ Site A } & To west & 49 & 26 & 23 & 56 & 30 & 28 & Decrease & Decrease & Decrease \\
& To east & 44 & 25 & 25 & 50 & 31 & 29 & Decrease & Decrease & No change \\
\multirow{2}{*}{ Site B } & To north & 51 & 33 & 36 & 60 & 40 & 44 & Decrease & Decrease & Increase \\
& To south & 52 & 33 & 37 & 61 & 39 & 44 & Decrease & Decrease & Increase \\
\multirow{2}{*}{ Site C } & To north & 51 & 29 & 29 & 59 & 36 & 35 & Decrease & Decrease & No change \\
& To south & 55 & 30 & 30 & 65 & 38 & 37 & Decrease & Decrease & No change \\
\hline
\end{tabular}

* Based on the statistical analyses of mean speeds and speed distributions. Decrease/Increase means a statistically significant change, with $\mathrm{p}<0.05$.

Table 4. Summary of changes in road user behaviors in Israeli sites following the installation of raised pedestrian crosswalks.

\begin{tabular}{|c|c|c|c|c|c|c|}
\hline Site & $\begin{array}{l}\text { Direction } \\
\text { of travel }\end{array}$ & $\begin{array}{l}\% \text { of giving-way } \\
\text { to pedestrians, on } \\
\text { near lane }\end{array}$ & $\begin{array}{l}\% \text { of giving-way } \\
\text { to pedestrians, on } \\
\text { far lane }\end{array}$ & $\begin{array}{l}\% \text { of full crossings } \\
\text { in the crosswalk } \\
\text { area }\end{array}$ & $\begin{array}{l}\% \text { of pedestrian } \\
\text { stoppings before } \\
\text { the crossing }\end{array}$ & $\begin{array}{l}\% \text { of checking } \\
\text { traffic before the } \\
\text { crossing }\end{array}$ \\
\hline \multirow[t]{2}{*}{ Site A } & To west & $\begin{array}{l}\text { I, from } 80 \% \\
\text { to } 96 \%\end{array}$ & $\begin{array}{l}\text { I, from } 63 \% \\
\text { to } 98 \%\end{array}$ & $\begin{array}{l}\text { I, from } 79 \% \\
\text { to } 98 \%\end{array}$ & $\begin{array}{l}\mathrm{D}, \text { from } 48 \% \\
\text { to } 33 \%\end{array}$ & $\begin{array}{l}\text { I, from } 89 \% \\
\text { to } 99 \%\end{array}$ \\
\hline & To east & $\begin{array}{l}\text { I, from } 80 \% \\
\text { to } 98 \%\end{array}$ & $\begin{array}{l}\text { I, from } 62 \% \\
\text { to } 100 \%\end{array}$ & $\begin{array}{l}\text { I, from } 75 \% \\
\text { to } 87 \%\end{array}$ & ns $(28-30 \%)$ & $\begin{array}{l}\text { I, from } 86 \% \\
\text { to } 99 \%\end{array}$ \\
\hline \multirow[t]{2}{*}{ Site B } & To north & ns (100\%) & ns (100\%) & $\begin{array}{l}\text { D, from } 96 \% \\
\text { to } 93 \%\end{array}$ & $\begin{array}{l}\mathrm{I}, \text { from } 5 \% \\
\text { to } 8 \%\end{array}$ & ns (100\%) \\
\hline & To south & $\begin{array}{l}I^{*}, \text { from } 99 \% \\
\text { to } 100 \%\end{array}$ & ns (99-100\%) & ns (94\%) & $\begin{array}{l}\mathrm{I}, \text { from } 8 \% \\
\text { to } 12 \%\end{array}$ & ns (100\%) \\
\hline \multirow[t]{2}{*}{ Site C } & To north & ns (88-100\%) & ns (92-100\%) & $\begin{array}{l}\text { I, from } 79 \% \\
\text { to } 89 \%\end{array}$ & $\begin{array}{l}\mathrm{D}, \text { from } 19 \% \\
\text { to } 10 \%\end{array}$ & $\begin{array}{l}\text { I, from } 94 \% \\
\text { to } 100 \%\end{array}$ \\
\hline & To south & ns (100\%) & ns (100\%) & $\begin{array}{l}\mathrm{I}^{*}, \text { from } 71 \% \\
\text { to } 82 \%\end{array}$ & ns (18-26\%) & $\begin{array}{l}\text { I, from } 90 \% \\
\text { to } 100 \%\end{array}$ \\
\hline
\end{tabular}

Notes: D - decrease, I - increase. Results reported in the table are based on the comparison of after 2 vs. before periods.

$\mathrm{D} /$ I indicates a statistically significant change, with $\mathrm{p}<0.05$; ns - not significant. ${ }^{*}$ Close to significant difference, $\mathrm{p}<0.1$. 
At Site B, with the smoother design (lower speed humps), installation of the raised crosswalk was associated with mean travel speeds of over $30 \mathrm{~km} / \mathrm{h}$ and 85 -percentile speeds of about $40 \mathrm{~km} / \mathrm{h}$ or higher. Following the treatment, the reduction in travel speeds was $10-15 \mathrm{~km} / \mathrm{h}$ lower compared to Sites A and C, in both mean and 85-percentile speeds. In addition, the immediate speed reductions were stronger than those observed after two months.

Table 4 presents a summary of changes in other road-user behaviors at the crosswalk area that were observed at the study sites. It shows that additional positive changes associated with the stronger setting (at Sites A and C) concerned a remarkable increase in the share of vehicles yielding to pedestrians in the crosswalk zone (particularly at site A, from $80 \%$ to $96-98 \%$ in the near lane, and from $62-63 \%$ to $98-100 \%$ in the far lane). There was also an increase in the share of pedestrians who performed a full crossing in the designated zone. At Site B with the smoother layout, yielding rates were close to $100 \%$ already in the before period and the bolder design did not seem to be required.

Regarding the extent of following the safe crossing rules by pedestrians (stopping before the crossing and checking the traffic before crossing), mixed changes were observed (see Table 4). In general, the treatment was associated with an increase in the share of pedestrians checking the traffic before the crossing but also with a decrease in the share of those who stopped before the crossing. The latter may reflect a better feeling of safety imparted to pedestrians by the raised crosswalks.

\subsection{Test sites in Sweden}

School children aged 9 to 12 pointed out the sites Dragonstigen and Tessins väg as two of the most dangerous sites in the neighborhood of the school. Therefore, the Tessins väg/Henrik Wranérs gata crossing was reconstructed to improve security and safety (Figure 11). As the two sites have different distances between speed cushion and pedestrian crossing, these two sites became test sites in Malmö. Unexpectedly, speed was somewhat lower on the pedestrian crossing at the side where the speed cushion was located further away, with a 90-percentile speed of $30 \mathrm{~km} / \mathrm{h}$ for the shorter distance and $2-3 \mathrm{~km} / \mathrm{h}$ lower for the longer distance, see Table 5. An explanation can be that with the speed cushion at a shorter distance from the pedestrian crossing, drivers are more focused on passing the speed cushion and therefore adjust their speed less to the approaching crossing compared to when the speed cushion is situated at a further distance. Speeds $12 \mathrm{~m}$ before the speed cushion were also measured, and the speeds $12 \mathrm{~m}$ before the pedestrian crossing was similar to that on the crossing with the exceptions of one direction at Dragonstigen. Vehicle speeds are assumed to be at their minimum at the speed cushions. Thus, the fact that the speed $12 \mathrm{~m}$ before the crossing was the same or less than at the crossing can most plausibly be explained by drivers starting to decelerate in order to drive over the speed cushion and then starting to accelerate again once they reach the crossing. At the time speed measurements in Borås were carried out, the measuring accuracy was not sufficient for stating exact speed at the pe-

Table 5. Free vehicle speeds $(\mathrm{km} / \mathrm{h}) 12 \mathrm{~m}$ before and at the pedestrian crossing depending on short (5.1 $\mathrm{m})$ or long distance ( $(8.8 \mathrm{~m})$ between speed cushion and pedestrian crossing. (PCR = pedestrian crossing). Johansson, Rosander \&Leden (2011).

\begin{tabular}{llcccc}
\hline & & \multicolumn{2}{c}{ Shorter distance } & \multicolumn{2}{c}{ Longer distance } \\
\cline { 3 - 6 } & & $12 \mathrm{~m}$ before PCR & On PCR & $12 \mathrm{~m}$ before PCR & On PCR \\
\hline \multirow{2}{*}{ Dragonstigen } & mean & 24.2 & 23.1 & 17.0 & 22.1 \\
& std dev (mean) & 1.51 & 1.21 & 0.59 & 0.51 \\
& $90 \%$ & 34 & 30 & 23 & 27 \\
& $\mathrm{~N}$ & 37 & 34 & 52 & 53 \\
\hline \multirow{2}{*}{ Tessins väg } & mean & 23.6 & 23.9 & 23.8 & 22.5 \\
& std dev (mean) & 0.68 & 0.65 & 0.54 & 0.43 \\
& $90 \%$ & 29 & 30 & 30 & 28 \\
& $\mathrm{~N}$ & 39 & 45 & 117 & 132 \\
\hline
\end{tabular}


destrian crossing. (Johansson, Rosander, \& Leden, 2011). We have still included the site since speeds were very similar to those in Malmö, and the behavioral studies were useful.

A total of 802 pedestrians were recorded when encountering a vehicle. Pedestrians were more often given way by the first driver in the near lane if there was a longer distance between the crossing and the speed cushion, $50 \%$ at longer distances compared with $40 \%$ at shorter distance $(p<0.05)$. Based on all 255 pedestrian observations from Dragonstigen, the tendency was the same, 50\% compared with $43 \%$ for all pedestrians, and on Hultagatan in Borås $43 \%$ compared to $23 \%$ for all pedestrians $(p<0.01)$. For child pedestrians at Dragonstigen, the difference was even greater, 57\% compared with $35 \%$ for children (according to a memorandum written by C. Johansson on 16 January 2004). On Tessins väg, the result concerning drivers' yielding behavior was just the opposite compared to the two other sites. This may possibly be due to lower visibility at the shorter distance compared to the longer distance.

The school survey revealed that some children had problems with predicting whether motor vehicle drivers intended to stop or not, especially at Dragonstigen. Two of the children interviewed at the location had pointed out this problem in the survey. When interviewed on the site, the children stated that it is problematic to foresee if motor vehicle drivers intended to stop or not when they slow down for the speed cushion. The problem seemed to be accentuat- ed when the speed cushion was situated closer (about $5 \mathrm{~m}$ ) to the crosswalk (Leden, Johansson \& Leden, 2006). This is probably since it is easier for the children to judge if the driver will be braking for them or for the speed-reducing device at the side where the device is located further away. To conclude, locating a speed-reducing device about $10 \mathrm{~m}$ before the crosswalk is more effective than $5 \mathrm{~m}$ before it (Johansson, Rosander \& Leden, 2011).

To summarize, a placement of speed humps in the range of 20 to $10 \mathrm{~m}$ before the crosswalk support 'ideal interactions' from the point of view of the pedestrian; and children crossing receive a stronger message about whether drivers intend to stop or not. When the speed cushion is situated at a longer distance from the pedestrian, drivers are more aware of the approaching pedestrian crossing as they then get more time to focus on approaching pedestrians and cyclists after passing the speed cushion.

\subsection{Summary of behaviors observed}

Table 6 provides a summary of behaviors observed at the treatment sites in Israel and in Sweden. As obvious, all infrastructure solutions were effective in reducing vehicle speeds at the crosswalk area and in attaining higher rates of drivers of motor vehicles giving way to pedestrians. However, stronger safetyrelated effects were observed at the sites with higher speed humps (in Israel) and when speed cushions were set at a longer distance from the crosswalk (in Sweden).

Table 6. Summary of behaviors observed at the test sites.

\begin{tabular}{|c|c|c|c|}
\hline Test sites & Main features of the measure & $\begin{array}{l}\text { Speeds at the crosswalk area, after } \\
\text { the treatment }\end{array}$ & $\begin{array}{l}\text { Share giving way to } \\
\text { pedestrians, after the } \\
\text { treatment }\end{array}$ \\
\hline \multirow[t]{2}{*}{ Israeli test sites } & $\begin{array}{l}15 \mathrm{~cm} \text { trapezoidal speed hump at the } \\
\text { crosswalk, } 8-10 \mathrm{~cm} \text { circular humps } \\
15-20 \mathrm{~m} \text { before the crosswalk }\end{array}$ & $\begin{array}{l}\text { Mean speeds of } 25-30 \mathrm{~km} / \mathrm{h} \text {, } \\
85 \% \text { speeds of } 30-38 \mathrm{~km} / \mathrm{h} \\
\text { (reductions of } 20-30 \mathrm{~km} / \mathrm{h} \text {, in both } \\
\text { indicators) }\end{array}$ & About $100 \%$ (an increase) \\
\hline & $\begin{array}{l}10-12 \mathrm{~cm} \text { trapezoidal speed } \\
\text { hump at the crosswalk, } 6-8 \mathrm{~cm} \\
\text { circular humps } 15-20 \mathrm{~m} \text { before the } \\
\text { crosswalk }\end{array}$ & $\begin{array}{l}\text { Mean speeds of } 33-37 \mathrm{~km} / \mathrm{h} \text {, } \\
85 \% \text { speeds of } 40-44 \mathrm{~km} / \mathrm{h} \\
\text { (reductions of } 10-15 \mathrm{~km} / \mathrm{h} \text {, in both } \\
\text { indicators) }\end{array}$ & About $100 \%$ (no change) \\
\hline \multirow[t]{2}{*}{ Swedish test sites } & $\begin{array}{l}7-10 \mathrm{~cm} \text { speed cushions } 8-10 \mathrm{~m} \\
\text { (Hultag, } 5 \mathrm{~m} \text { ) before the crosswalk }\end{array}$ & $\begin{array}{l}\text { Mean speeds of } 22 \mathrm{~km} / \mathrm{h} \text {, } \\
90 \% \text { speeds of } 27-28 \mathrm{~km} / \mathrm{h}\end{array}$ & $\begin{array}{l}50 \% \text { of giving way by first } \\
\text { vehicle }\end{array}$ \\
\hline & $\begin{array}{l}7-10 \mathrm{~cm} \text { speed cushions } 4-5 \mathrm{~m} \\
\text { (Hultag } 3 \mathrm{~m} \text { ) before the crosswalk }\end{array}$ & $\begin{array}{l}\text { Mean speeds of } 23-24 \mathrm{~km} / \mathrm{h} \text {, } \\
90 \% \text { speeds of } 30 \mathrm{~km} / \mathrm{h}\end{array}$ & $\begin{array}{l}40 \% \text { of giving way by first } \\
\text { vehicle }\end{array}$ \\
\hline
\end{tabular}




\subsection{Yield and stop lines}

Gitelman et al (2017) concludes that the Israeli design has a potential for reducing multiple-threat conflicts occurring due to a vehicle overtaking a stopped car in the adjacent lane, which is a hazard especially to crossing children (Leden, Gårder \& Johansson, 2006). To achieve a stronger message to alert drivers to stop and not to overtake a stopped car or truck in the adjacent lane, advanced yield or stop lines are needed. Adding yield or stop lines in advance of the crosswalk is likely to be more efficient if it is accompanied by a comprehensive information campaign explaining the message. However, installing yield lines is not yet an option available in many countries. For example, according to Finnish and Israeli regulations, yield or stop lines cannot be installed except for at signalized crosswalks, though it is already used in, for example, Spain, Japan and the United States - see examples in Figures 13, 14 and 15. In Sweden, yield bars must be used at marked crossings for cyclists, which also should be speed secured to about $30 \mathrm{~km} / \mathrm{h}$, but yield bars are not mandated at pedestrian crosswalks (SKL, 2015).

The US guideline MUTCD (2009) recommends a distance between yield bars and a crosswalk of 6 to $15 \mathrm{~m}$. An example from an intersection in Los Angeles is given in Figure 14. The midblock design according to Figure 3B-17 in MUTCD (2009) is shown in Figure 15. It is also recommended to consider using advanced warning markings for speed humps.

\section{DISCUSSION AND CONCLUSIONS}

As established in the introduction, the key issue when children aged 7-12 years are to cross a street is to secure speeds of $20 \mathrm{~km} / \mathrm{h}$ or lower. An effective option for achieving this is to implement speed cameras to survey a posted speed limit of $20 \mathrm{~km} / \mathrm{h}$. An example is given in Figure 16, which shows a speed camera surveying a regulatory speed, posted by sign and marked in the carriage way, at a crosswalk which had more pedestrian injuries than any other location in Helsinki prior to the camera being installed. Studies from the state of Victoria, Australia, show that over $99.9 \%$ of drivers in 2017 stayed below the posted speed at locations with fixed cameras that had a zero-speed enforcement margin (Driver Compliance, 2018). Further development of intelligent "platforms" or speed-activated trapdoors type Edeva (2016) is another option to secure speeds of $20 \mathrm{~km} / \mathrm{h}$ (Gustafs-

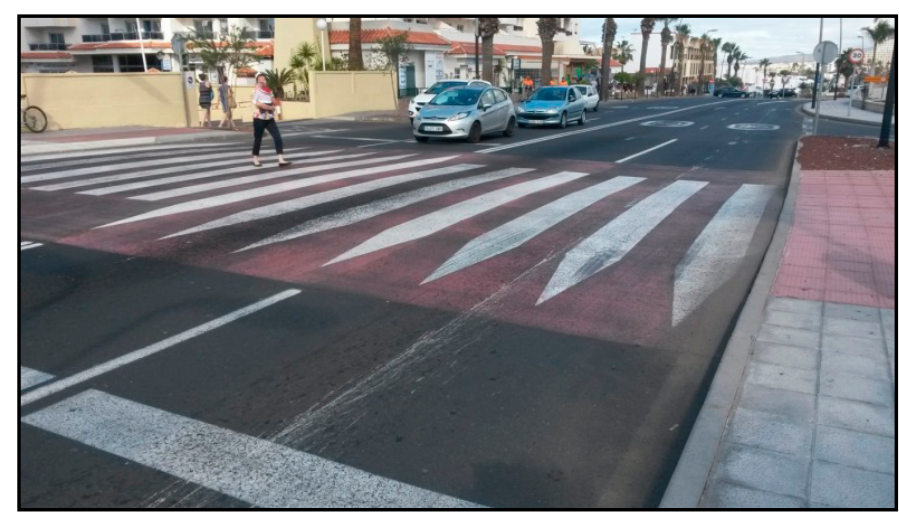

Figure 13. Speed-reducing devices and stop lines or yield bars 8 to $10 \mathrm{~m}$ before the crosswalk Playa de las Americanos Arquitecto Gomez Cuesto, Tenerife.

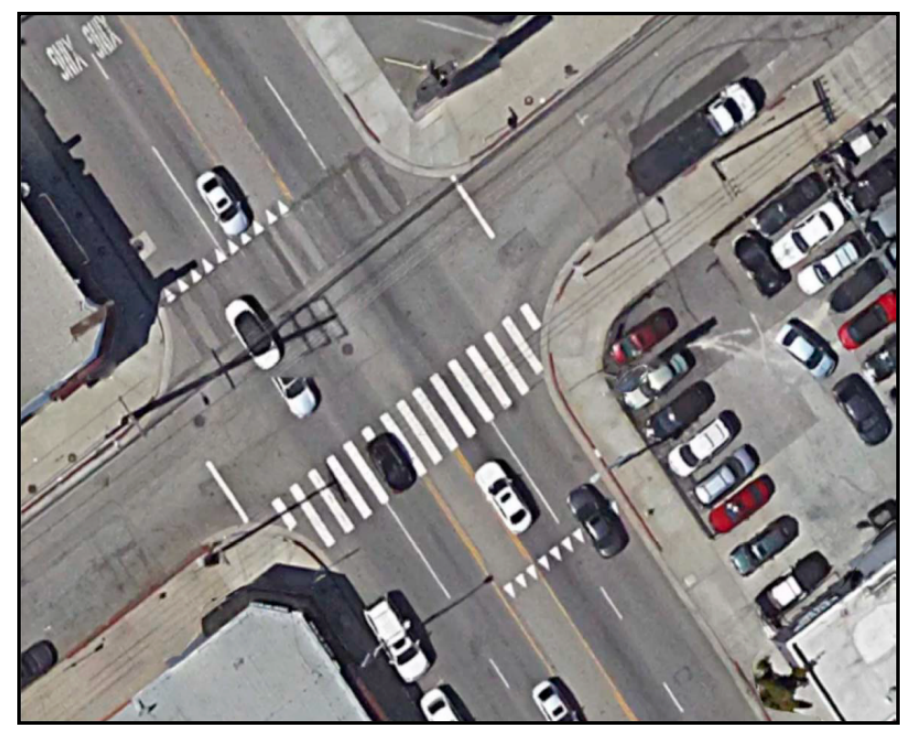

Figure 14. 'Early' yield lines at intersection, Los Angeles, USA.

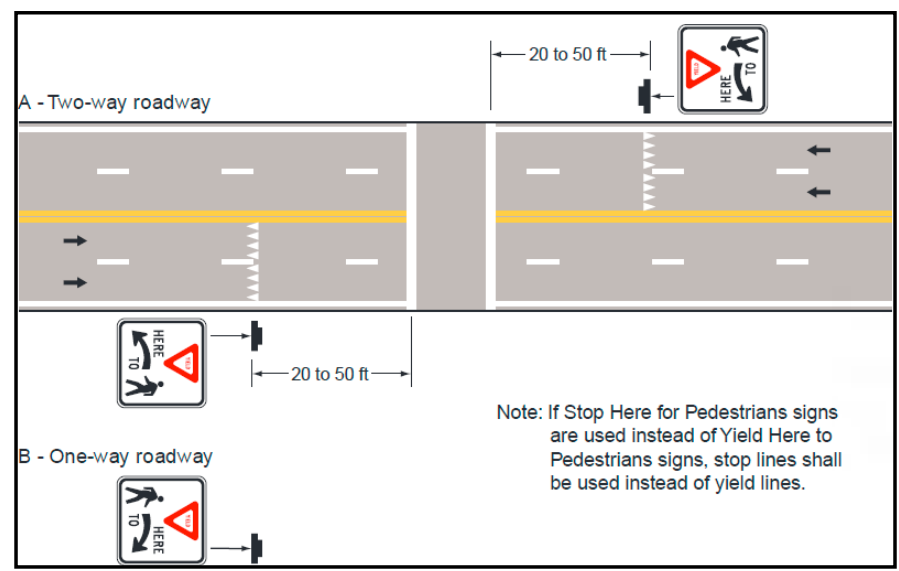

Figure 15. Location of yield lines at unsignalized midblock crossing according to MUTCD (2009).

son, Jägerbrand \& Grumert, 2011). Ideally, the street should have a speed-reducing device that is clearly felt by drivers going above the desired speed but the street should be kept flat and comfortable for road- 
users traveling at or below the desired speed. This is of special benefit to standing passengers in buses and to patients traveling in ambulances.

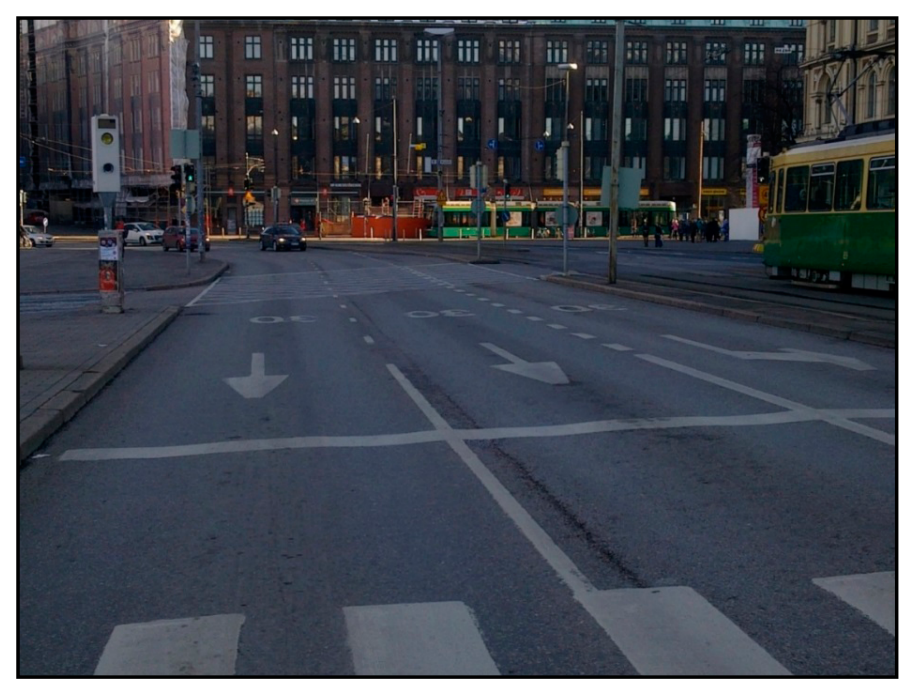

Figure 16. Speed camera surveying a posted speed.

To summarize, our presumption is that actual vehicle speeds should be below $20 \mathrm{~km} / \mathrm{h}$ where children (aged7 to 12 years) are crossing a street, especially if they are walking unaccompanied by an adult where children (aged 7 to 12 years old) are crossing a street, especially if they are walking unaccompanied by an adult. The results of field studies show that a "best design" to reach this should include a speed-reducing device located before the crosswalk. The optimal distance from such a device to the crosswalk is about $10 \mathrm{~m}$ if the speed limit is $30 \mathrm{~km} / \mathrm{h}$ or lower. For streets with $50 \mathrm{~km} / \mathrm{h}$ speed limits, a longer distance of 15 to $20 \mathrm{~m}$ is needed and, and as a complimentary measure, the crosswalk itself should also be elevated. Advanced yield bars or stop lines before the crosswalk are needed to give a stronger message to alert drivers to stop, and not to overtake a stopped car in an adjacent lane on multi-lane arterials. A distance to the crosswalk of about $10 \mathrm{~m}$ is recommended (Várhelyi \& Leden, discussion at ICTCT, 2016). To secure travel speeds below $20 \mathrm{~km} / \mathrm{h}$ additional measures like camera enforced speeds near the crosswalk might be needed.

In few years, ITS technology may govern speeds at marked crosswalks, and speed-reducing measures will be less needed at that time. However, for the foreseeable future, older vehicles lacking such technology will still be allowed on streets and even in newer vehicles, speed-control systems may be voluntary and possible to switch off. Therefore, we are of the opinion that investments into the measures discussed in this paper will have a role to play for decades to come.

\section{EPILOGUE}

Back in the late 1970s, it took four years to form a working group, gather available knowledge about speed-reducing measures, analyze, initiate tests, synthesize information, draft new Swedish guidelines, consult available experts, redraft and publish an official "best practice" concerning speed-reducing devices on local streets in residential areas. That was published by the Swedish Road Safety Office TSV (Leden, Andersson \& Källström, 1982). It was published at a time when the Swedish traffic engineers desperately were looking for advice on how to design speed-reducing devices and an efficient network was in place to disseminate the information and it became a success story. Now it is urgent to promote a 'best' design also for crosswalks across multi-lane arterials, especially near schools and in 'busy' city districts with high pedestrian activity including children, and to establish a network to support their implementation.

Acknowledgements: Thanks to Prof. András Várhelyi for valuable inputs concerning how to achieve 'ideal interactions', to Mr. Marek Salermo at the City of Helsinki and to Mr. Per Wramborg at the Swedish National Road Administration for never-ending support for our research concerning a base for developing guidelines for a safe traffic environment for children. Dr. Anita Gärling, Prof. Christoph Hupfer, Prof. Risto Kulmala, Dr. Iren Papp, Dr. Eirin Ryeng, Prof. Hartmut Topp and Dr. András Várhelyi should have a special thanks for answering the expert questionnaire, see chapter 2, and Dr. Eirin Ryeng is also given special thanks for sharing her outline of the coding of behaviors of pedestrians and cyclists.

\section{REFERENCES}

Arnold, P. K. \& Bennett, R. G. (1990). The Human Factors Approach to Improving Pedestrian Safety. Proceedings RoadwatchInaugural Annual Conference. Nedlands, Western Australia.

Barbosa, H., Tight, M. R. \& May, A. D. (2000). A Model of Speed Profiles for Traffic Calmed Roads. Transport Research Part A 34. pp. 103-123

Connely, M. L., Conaglen, H. M., Parson, B.S. \& Isler, R. B. (1998). Child Pedestrians Crossing Gap Thresholds. Accident Analysis and Prevention. Vol. 30, No. 4, pp.443-453.

Daniel, J., Chien, S. \& Liu, R. (2005). Effectiveness of Certain Design Solutions on Reducing Vehicle Speeds. New Jersey Institute of Technology. 
Driver Compliance. (2018). Cameras Save Lives, the Department of Justice and Regulation, Victoria State Government, retrieved from https://www.camerassavelives.vic.gov.au/roadsafety/statistics/driver-compliance (accessed 2018-04-01)

Edeva (2016) Retrieved from https://www.edeva.se/se/ (accessed 2016-12-13)

Ekman, L. (1997). Fotgängares situation vid övergångställe-En litteraturstudie. (The Situation of Pedestrians at Crosswalksa Literature Study). Institutionen för Trafikteknik, Tekniska Högskolan, Lund. Sweden.

Fontaine, M. D. \& Carlson, P. J. (2001). Evaluation of speed displays and rumple strips at rural maintenance work zones. Transportation Research Record, 1754, pp. 27-38.

Foot, H., Tolmie, A., Thomson, J., McLaren, B. \& Whelan, K. (1999). Recognizing the Hazards. The Psychologist 199/08.12, 400-402.

Gitelman, V., Carmel, R., Pesahov, F. \& Chen, S. (2017). Changes in road user behaviour following the installation of raised pedestrian crossings on urban arterial. Transport Research Part F Psychology. Volume 46, Part B, April 2017, 356-372

Gregersen N. P. (2016) Trafiksäkerhet. Samspelet mellan människor, fordon och trafikmiljö. Wolters Kluwer.

Gustafsson, S., Jägerbrand A. K. \& Grumert, E. (2011). Traffic calming measures in new traffic environments and the use of ITS. VTI notat 17-2011 Linköping, Sweden. Retrieved from https://www.diva-portal.org/smash/get/diva2:670463/FULLTEXT01.pdf

Harkey, D.L. \& Zegeer, C.V. (2004). PEDSAFE: Pedestrian safety guide and countermeasure selection system. Report No. FHWA-SA-04-003. Federal Highway Administration, Washington, DC.

Höskuldur R. G. K. (2015). Accidents between pedestrians, bicyclists and motorized vehicles: Accident risk and injury severity. Lund university. Department of Technology and Society. Doctoral thesis.

Johansson, C. (2001). Towards a Method to Improve Road Safety for Pedestrians and Cyclists Especially in Child Pedestrian Environments: A Case Study in Borås, Sweden. Luleå University of Technology. Licentiate Thesis 2001:29.

Johansson, C. (2004). Safety and Mobility of Children Crossing Streets as Pedestrians and Bicyclists. Luleå University of Technology. Doctoral Thesis 2004:27.

Johansson, C. \& Leden, L. (2007). Short-term effects of countermeasures for improved safety and mobility at marked pedestrian crosswalks in Borås, Sweden. Accident Analysis \& Prevention. 39, 3, 500-509.

Johansson, C. \& Leden, L. (2010). Child Pedestrians' Quality Needs and how these needs relate to interventions. In Proceedings of Walk21, ICTCT Conference the Hague November 17-19. Retrieved from http://www.ictct.org/workshops/denhague-netherlands/

Johansson, C., Leden, L., Wilhelmsson, O., Nilsson. K. (1999). Towards a Safe Traffic Environment for Children - a Starting Point. 12th ICTCT Workshop Kaiserslautern 1999, Germany.
Johansson, C. \& Rosander, P. (2006). Tessins väg i Malmö - ett exempel på hur barn medverkar i processen om gatumiljöns förnyelse. Arbetsrapport. ISSN 1402-9774 Luleå tekniska universitet 2006:7

Johansson, C., Rosander, P. \& Leden, L. (2011). Distance between Speed Humps and Pedestrian Crossings: Does it Matter? Accident Analysis and Prevention 43, 1846-1851.

Karlgren, J. (2001). Bilars hastighet längs gator med gupp. Metod för framställning av hastighetsprofiler och analys av hastighetsförlopp. Doctoral thesis Chalmers tekniska högskola.

Leden, L. (1989). The safety of cycling children. The safety of the street environment. Technical Research Centre of Finland. Publications 55.

Leden, L., Andersson, K. \& Källström, L. (1982). Speed reducing devices in residential areas. The Swedish Traffic Safety Office. Report No. 4. Borlänge.

Leden, L., Gårder, G. \& Johansson, C. (2006). Safe pedestrian crossings for children and elderly. Accident Analysis and Prevention 38. 289-294

Leden, L., Johansson, C. \& Leden, L. (2006). Skolenkät och intervjuer om ombyggnaden av Tessins väg vid Fridhemsskolan i Malmö i maj 2006 - ett underlag för att utvärdera effekten av ombyggnaden av Tessins väg. Arbetsrapport 2006:5 Luleå University of Technology.

Light; R. J. \& Pillimer, D. B. (1984). Summing up. The science of reviewing research. Harvard University Press. ISBN 0-67485431-4

MacGregor, C., Smiley, A. \& Dunk, W. (1999). Identifying Gaps in Child Pedestrian Safety. Comparing What Children Do with What Parents Teach. Transportation Research Record 1674. Paper no. 990724.

Morrongiello, B., A., Corbett, M., Milanovic, BA \& Beer, J. (2015). Using a Virtual Environment to Examine How Children Cross Streets: Advancing Our Understanding of How Injury Risk Arises. Journal of Pediatric Psychology. 1-11

Morrongiello, B., A., Corbett, M. (2015). Using a Virtual Environment to study child pedestrians behaviours: a comparison of parents 'expectations and children's street crossing Inj. Prev. 2015; 21:291-295. doi:10.1136/injuryprev-2014-041508

MoT (2002). Ministry of Transport. Guidelines for speed humps' design and application. Jerusalem, Israel.

MUTCD (2009). Manual on Uniform Traffic Control Devices for Streets and Highways. Federal Highway Administration, US Department of Transportation, Figure 3B-31. Retrieved from http:// mutcd.fhwa.dot.gov/pdfs/2009r1r2/mutcd2009r1r2edition.pdf

Øvstedal,L., Ryeng, E. Registrering av barns atferd på skolevei. SINTEF rapport STF22A99556, Trondheim. (1999).

Rosander, P, Lyckman, M. \& Johansson, C. (2007). Förhöjda övergångsställen för alla trafikanter - en studie om farthinder. Teknisk rapport. ISSN 1402 - 1536 Luleå tekniska universitet 2007:08

SKL (2015). Förslag till utformning av cykelöverfart. Informationsmaterial. Sveriges Kommuner och Landsting 2015-06-16 rev. 2015-06-23 
Sørensen; M. W, J. (2010).Trafikksikkerhedshåndboken 3.24 Sambruksområde (Shared space). Oslo, TØI http://tsh.toi. no/324-sambruksomraade.htm

Turner, S., Fitzpatrick, K., Brewer, M. \& Park, E.S. (2006). Motorist yielding to pedestrians at unsignalized intersections. Findings from a national study on improving pedestrian safety. Transportation Research Record 1-12

Towliat, M. (2001). Effects of Safety Measures for Pedestrians and Cyclists at Crossing Facilities on Arterial Roads. Lund institute of Technology. Doctoral Thesis Bulletin 195.

Várhelyi A. (1996). Dynamic Speed Adaptation Based on Information Technology: A Theoretical Background. PhD-thesis, Lund University, Sweden

Várhelyi A. (1998). Drivers' speed behaviour at a zebra crossing: a case study. Accident Analysis and Prevention 30(6), 731-43 (Article based on Várhelyi's thesis.)

VGU (2015). Vägars och Gators Utformning. VGU guidelines for geometric design of roads and streets (Sweden). Trafikverkets publikation 2015:087 